\title{
Karlovy Vary 2005
}

\author{
By Ron Holloway
}

Fall 2005 Issue of KINEMA

\section{KARLOVY VARY INTERNATIONAL FILM FESTIVAL 2005}

"Life Begins at Forty!" ran the trailer for this year's $40^{\text {th }}$ Karlovy Vary International Film Festival (1-9 July 2005). But, as some asked, was this really the $40^{\text {th }}$ anniversary? Since the festival was officially founded in the summer of 1946 - thus making it older than Cannes, founded in September of 1946 - then KVIFF should rightly be 59 years old, in contrast to the $58^{\text {th }}$ anniversary celebrated by Cannes last May. There are two bumps in the road, however. First of all, the Czech event was programmed in the neighbouring spa of Marienbad for its first three years, not in Karlovy Vary at all. Secondly, beginning in 1958 and lasting until 1994, Karlovy Vary was forced by a FIAPF (International Federation of Film Producers Associations) recommendation to alternate annually with Moscow. This festival carousel went on until 1994, when both Karlovy Vary and Moscow scheduled annual festivals in the summer a few weeks apart from each other.

Be that as it may, Karlovy Vary celebrated its $40^{\text {th }}$ birthday in grand style. Shortly after festival director Jiří Bartoška and artistic director Eva Zaoralová welcomed an assembly of prominent guests - including both Czech President Václav Klaus and retired President Václav Havel - the curtain was raised on a gigantic papier-maché birthday cake, upon which danced forty smiling little girls dressed as candles. A screen in the background flashed spots from previous festival trailers - before this year's trailer, produced by filmmaker David Ondříček, chronicled in leaps the progression over the years of a sassy baby to a burnt-out adult to a recharged male on his $40^{\text {th }}$ birthday.

The icing on the birthday cake was a warm welcome extended to three film personalities. Jiří Krejčík, a veteran Czech director, was honoured with a screening of his Vyšš princip (A Higher Principle, 1960), a drama about courage and cowardice as experienced by a teacher in a provincial town shortly after the Second World War. Then the audience in the Great Hall with its 12,000 seats rose in unison to greet Robert Redford, honoured with a retrospective, and Madeleine Albright, the first woman secretary of state who was born in Czechoslovakia. Redford, in turn, saluted the achievements of Václav Havel in the audience, praising his engagement and fighting spirit during the period of Neo-Stalinism, and thanked the festival for welcoming back George Roy Hill's Butch Cassidy and the Sundance Kid (1969), a film I personally viewed here in Karlovy Vary back in 1969 in the presence of actress Katherine Ross.

Later, during the festival week, Liv Ulmann was also on hand for her retrospective as part of the tribute to "Nature and Landscape in Norwegian Cinema." Among other VIP guests were Sharon Stone and Viviane Reding, the European Commissioner for Information, Society and Media. Cineastes were also treated to the masterpieces of the great Japanese director Kihachiro Kawamoto, whose work in puppet animation over the past three decades is equalled only by the Czech master Jiří Trnka.

Karlovy Vary, aka Karlsbad, is a favourite festival of many film professionals. Hotels and villas, national monuments and cure centres have all been restored, among them the splendid rococo Divadlo (Theatre), built in 1886 and opened back then with a performance of Mozart's The Wedding of Figaro. Students and young cineastes from across the Czech Republic and Slovakia flock to this resort spa with backpacks, many of them sleeping in the park or under the stairs of the Hotel Thermal when it rains. With lines forming before the box office as early at 7:00 in the morning, the only problem is making a decision as to the four films one is entitled to see with a Participation ID Pass, after which they are often given permission to sit on the floor at any one of the nine venues with 14 screens. The same long line forms again during the mid-afternoon hours before the computer stand. With 278 films programmed in 22 sections, in addition to daily music concerts, the KVIFF is a paradise for the culturally thirsty.

This year, three international juries were assembled at Karlovy Vary to judge the International Competition of Feature Films, the Documentary Competition, and the newly installed "East of the West" Competition of Films from Central and Eastern Europe. In the past, "East of the West" (thus named because in former socialist times Prague in the Eastern Bloc was further west on the map than Vienna in the Western Camp) 
was a Philip Morris showcase with a hefty purse award to whet the appetite. This time around, Philip Morris is still funding the award without its name directly attached to the purse. By coincidence, three of the main prizes in all three competitions were awarded to films from what was formerly known as "Eastern Europe."

Krzysztof Krauze's Moj Nikifor (My Nikifor, Poland) was awarded the Crystal Globe, the festival's Grand Prix. Further, Krzysztof Krause was awarded Best Director, while 80-year-old Krystyna Feldman in the title role was awarded Best Actress - a surprise decision, if you will, because this popular woman bit-player was chosen over a male actor to interpret the life-style of a legendary naive painter.

As the true-life story goes, Epifan Drowniak, also known as Nikifor Krynicki, was discovered in 1960 by another painter, Marian Wlosinski, who took him in and became his benefactor. Although physically handicapped and mentally disabled as well, Nikifor could paint beautiful primitive paintings in water-colours, which he then sold to guests at the Krynice spa (thus his nickname).

When his paintings were exhibited in a Paris gallery next to those of Rousseau, another master of naive art, Nikifor became famous overnight as a painter with a pure vision and stylistic grace. He died in 1968 of tuberculosis. Asked why he had chosen Krystyna Feldman, Krzysztof Krause gave a simple explanation: "Because she bears an uncanny resemblance to the real person."

A share of the First Prize in the Documentary Competition was awarded to Galina Adamovich's Boza moj (My God, Belarus). This warming 20-minute portrait of Julite Karmaza shows how a humble elderly villager with an eternal smile on her face goes about mixing cement to create pious sculptures - Jesus, the Virgin Mary, the Way of the Cross - and then carry them off to decorate cemeteries, shrines, and crossroads. Indeed, the entire landscape along the Belarus border to Lithuania is adorned with her remarkable works of homemade religious expression.

Kirill Serebrennikov's Ragin (Russia) was awarded the "East of the West" Prize. Yet another adaptation of Anton Chekhov's "Ward 6", the setting is a psychiatric clinic somewhere deep in the provinces at the beginning of the $20^{\text {th }}$ century. Ragin, the head doctor at the clinic, is obsessed with questionable experiments to find ways to help his mentally afflicted patients - until gradually, as in the Chekhov short story, he himself goes mad. Andrei Guskov gives a strong performance of a man on the brink of insanity in this debut feature film by a stage director and documentary filmmaker. According to Kirill Serebrennikov in an interview, Ragin personifies several pseudo-intellectuals in socialist times who bluffed their way to fame and fortune "a practice that unfortunately is common even today."

Two historical themes in the main competition were standouts. In Márta Masseurs's A temetetlen halott (The Unburied Man, Hungary) the last days of Imre Nagy are chronicled from a memoir written by his daughter Erzsebet. Even today, no one knows exactly where the murdered Hungarian President and former Premier is buried. Following the suppression of the Hungarian Revolt in 1956, Imre Nagy (1896-1958) was transported to Romania with members of his family, where a secret show trial was conducted that led to his execution. Mészáros approaches the theme as though she is documenting a diary, offering little political commentary or critical analysis of events. The fate of Imre Nagy is interpreted by Polish actor Jan Nowicki, a Mészáros' long-time favourite.

In Pavel Chukhrai's Voditel' dlya Very (A Driver for Vera, Russia) the fate of a fictional General Serov, a naval admiral, is narrated as though this is a true historical event, albeit with flourishes of melodrama to draw the viewer closer to the tragic elements in the story. The setting is Sevastopol in 1962, two years before the overthrow of Nikita Khrushchev that marked the end of the "Thaw". Knowing that he has enemies in government circles, who can resort to KGB methods without scruples, Serov wants to protect Vera, his pregnant handicapped daughter from the same fate. So he turns to his driver, a young cadet yearning to win a place in the military academy in Moscow, and asks him to marry Vera with the promise of promotion. All is in vain - everyone loses, save for the new-born baby.

Lensed by an outstanding cameraman, Igor Klebanov, the rugged Black Sea coast provides an apt backdrop for this historical drama of would-be winners and tragic losers. One might contend that in Vera's Driver Pavel Chukhrai is also paying his respects to his father, the legendary Grigory Chukhrai, whose Balada o soldate (Ballad of a Soldier, 1959) and Chistoye nebo (Clear Skies, 1961) were highlights of the Khrushchev 
"Thaw" period. Both films were made in the same period of time explored by Pavel Chukhrai in Vera's Driver.

\section{References}

AWARDS

INTERNATIONAL COMPETITION

Crystal Globe - Grand Prix: Moj Nikifor (My Nikifor, Poland), dir Krzysztof Krauze

Special Jury Prize: Eize makom nifla (What a Wonderful Place, Israel), dir Eyal Halfon

Best Director: Krzysztof Krauze, Moj Nikifor (My Nikifor, Poland)

Best Actress: Krystyna Feldman, Moj Nikifor (My Nikifor, Poland), dir Krzysztof Krauze

Best Actor (ex aequo): Luca Zingaretti, Alla luce del sole (Come into the Light, Italy), dir Roberto Faenza, and Uri Gavriel, Eize makom nifla (What a Wonderful Place, Israel), dir Eyal Halfon

Special Mention: Noriko no shokutaku (Noriko's Dinner Table, Japan), dir Sion Sono

DOCUMENTARY COMPETITION

Best Long Documentary: Estamira (Brazil), dir Marcos Prado

Special Mention: Mad Hot Ballroom (USA), Marilyn Agrelo

Best Short Documentary: Boza moj (My God, Belarus), dir Galina Adamovich

EAST OF THE WEST COMPETITION

Best Film: Ragin (Russia), dir Kirill Serebrennikov

Special Mention: Wesele (The Wedding, Poland), dir Wojtek Smarzowski

NON-STATUTORY AWARDS

International Critics (FIPRESCI) Prize: Kinamand (Chinaman, Denmark-China), dir Henrik Ruben Genz

Ecumenical Prize: Kinamand (Chinaman, Denmark-China), dir Henrik Ruben Genz

Don Quixote Prize (FICC - International Federation of Film Clubs): Noriko no Shokutaku (Noriko's Dinner Table, Japan), dir Sion Sono

Special Mention: Moj Nikifor (My Nikifor, Poland), dir Krzysztof Krauze

Young Czech Critics Jury Award - Another View section: Parvane ha badraghe mikonand (The Butterflies Are Just a Step Behind, Iran), dir. Mohammad Ebrahim Moaiery

Czech Television Award - Independent Camera Prize - Forum of Independents: Los Muertos (The Dead, Argentina), dir Lisandro Alonso

Pravo Audience Award: La vie avec mon père (Life with My Father, Canada), dir Sébastien Rose

Awards for Outstanding Artistic Contribution to World Cinema: Jiří Krejčík, Czech Republic, Robert Redford, USA, Sharon Stone, USA, Liv Ullmann, Norway

\section{Author Information}

Ron HOLLOWAY (1933-2009) was an American critic, film historian, filmmaker and correspondent who adopted Europe as his home in the early fifties and spent much of his life in Berlin. He was an expert on the study of German cinema and against all odds produced, with his wife Dorothea, the journal German Film, 
keeping us up-to-date with the work of directors, producers and writers and the showing of German films around the world.

In 2007, Ron Holloway and his wife were awarded the Berlinale Camera Award. Ron also received the Bundesverdienstkreuz (German Cross of Merit), Polish Rings, Cannes Gold Medaille, the American Cinema Foundation Award, the Diploma for Support of Russian Cinema and an honorary award from the German Film Critics' Association.

Ron was also a valued contributor to Kinema for the past fifteen years. 